\title{
Moving polewards in winter: a recent change in the migratory strategy of a pelagic seabird?
}

\author{
Petra Quillfeldt*1, Juan F Masello1, Rona AR McGill2, Mark Adams³ and Robert W Furness ${ }^{4}$
}

\begin{abstract}
Background: During the non-breeding period, many birds migrate to milder areas, found closer to the equator than their breeding sites. Opposite movements are very rare. In the Southern Ocean, the abundance of ${ }^{13} \mathrm{C}$ declines markedly with more southern latitude, providing a characteristic ${ }^{13} \mathrm{C}$ isoscape. This can be used as a tracer for the movement of seabirds between breeding and inter-breeding areas, by comparing stable isotope ratios of feathers grown at different times of the year.
\end{abstract}

Results: We studied seasonal movements of Thin-billed prions (Aves, Procellariiformes), breeding at the Subantarctic Falkland/Malvinas Islands, compared with those of Wilson's storm-petrels breeding in the Antarctic South Shetland Islands. The two species showed opposite migratory movements. While Wilson's storm-petrels moved to warmer waters north of the Drake Passage in winter, Thin-billed prions showed a reversed movement towards more polar waters. Carbon stable isotope ratios in recent and historical feathers indicated that poleward winter movements of Thin-billed prions were less common historically (45\% in 1913-1915), and have only recently become dominant (92\% in 2003-2005), apparently in response to warming sea temperatures.

Conclusions: This study shows that pelagic seabirds can rapidly change migration strategies within populations, including migration towards more poleward waters in winter.

\section{Background}

Migration is thought to be an adaptive strategy, when resources found in the breeding area during the breeding season become scarce during the non-breeding season or climate becomes unfavourable. Animals can then displace to more productive or milder areas [1]. The places animals select for the winter season are usually warmer, e.g. transequatorial to winter in the opposing hemisphere's summer, or further towards the equator within the same hemisphere (latitudinal migration) or lower in the mountains (altitudinal migration). Opposite movements are very rare, and virtually absent in terrestrial birds [1].

Many seabirds are too small to carry devices presently available for satellite or GPS tracking. Small pelagic seabirds are difficult to observe in their vast marine ecosystems, and little is known about their distribution and

*Correspondence: quillfeldt@orn.mpg.de

1 Max-Planck-Institut für Ornithologie, Vogelwarte Radolfzell, Schlossallee 2 78315 Radolfzell, Germany

Full list of author information is available at the end of the article behaviour outside the breeding season. Stable isotopes provide a powerful tool to study movements and trophic position of such birds if tissue grown at different times during the year can be matched to an isotopic gradient across the area of movement [2].

Since keratin is a highly stable molecule, the nitrogen and carbon isotopic composition of feathers remains unchanged after the completion of growth. Thus, historical feathers provide a window that allows us to look back in time, and stable isotope analysis can therefore be applied to study changes in migratory patterns due to environmental change. Historical feathers from museum specimens have been analysed for stable isotopes in few seabird species, chiefly to investigate reasons for population change. Declining $\delta^{15} \mathrm{~N}$ levels, indicative of declining trophic levels, were found in Northern Fulmars Fulmarus glacialis [3], and Marbled Murrelets [4,5]. Declining carbon isotope ratios were found in Rockhopper penguins Eudyptes chrysocome, and were interpreted as a decline in primary productivity and thus, the carrying capacity, of 
the ecosystem [6,7]. The aim of the present study is to use stable isotopes to understand the movements of a small pelagic seabird, both from recent and historical samples.

Previous studies suggested that the carbon stable isotope ratio $\delta^{13} \mathrm{C}$ in the Southern Ocean declines between 40 and $80^{\circ} \mathrm{S}$ [8-11]. By compiling data from the literature and modeling this trend, we here aim to verify if seasonal latitudinal movements of seabirds in the Southern Ocean will result in different $\delta^{13} \mathrm{C}$ values of adult feathers grown during winter, and chick feathers and induced adult feathers grown during the summer. The latter both represent the breeding season equally well and do not differ in their stable isotope ratios (see Methods).

We then applied the results of the spatial model to interpret data on seabird movements. Our focal species in this study was an abundant pelagic seabird in the Southern Ocean, the Thin-billed prion Pachyptila belcheri, sampled at a breeding site at New Island Nature Reserve in the Falkland/Malvinas Islands, at $52^{\circ} \mathrm{S}$ (Fig.
1B). Thin-billed prions breed on Sub-Antarctic islands. Their year-round distribution is poorly known. They are highly pelagic and mobile, scatter widely and are not attracted by ships, making their observation in Southern Ocean winter waters difficult. Based on stable isotopes of adult feathers grown during winter, it has been suggested recently that Thin-billed prions move towards more polar waters for the winter, both from their breeding populations from Kerguelen [12,13] and the Falkland Islands [10].

We included samples of Wilson's storm-petrels Oceanites oceanicus from a breeding site at the South Shetland Islands at $62^{\circ} \mathrm{S}$ (Fig. 1B), as a reference for the location $\left(\delta^{13} \mathrm{C}\right)$ and relative trophic level $\left(\delta^{15} \mathrm{~N}\right)$. Wilson's stormpetrels feed in Antarctic waters during the chick-rearing period, and are known to migrate north in winter $[9,14]$.

To compare historical and recent migration patterns, we obtained feather samples of Thin-billed prions from skin collections, including only birds collected during the

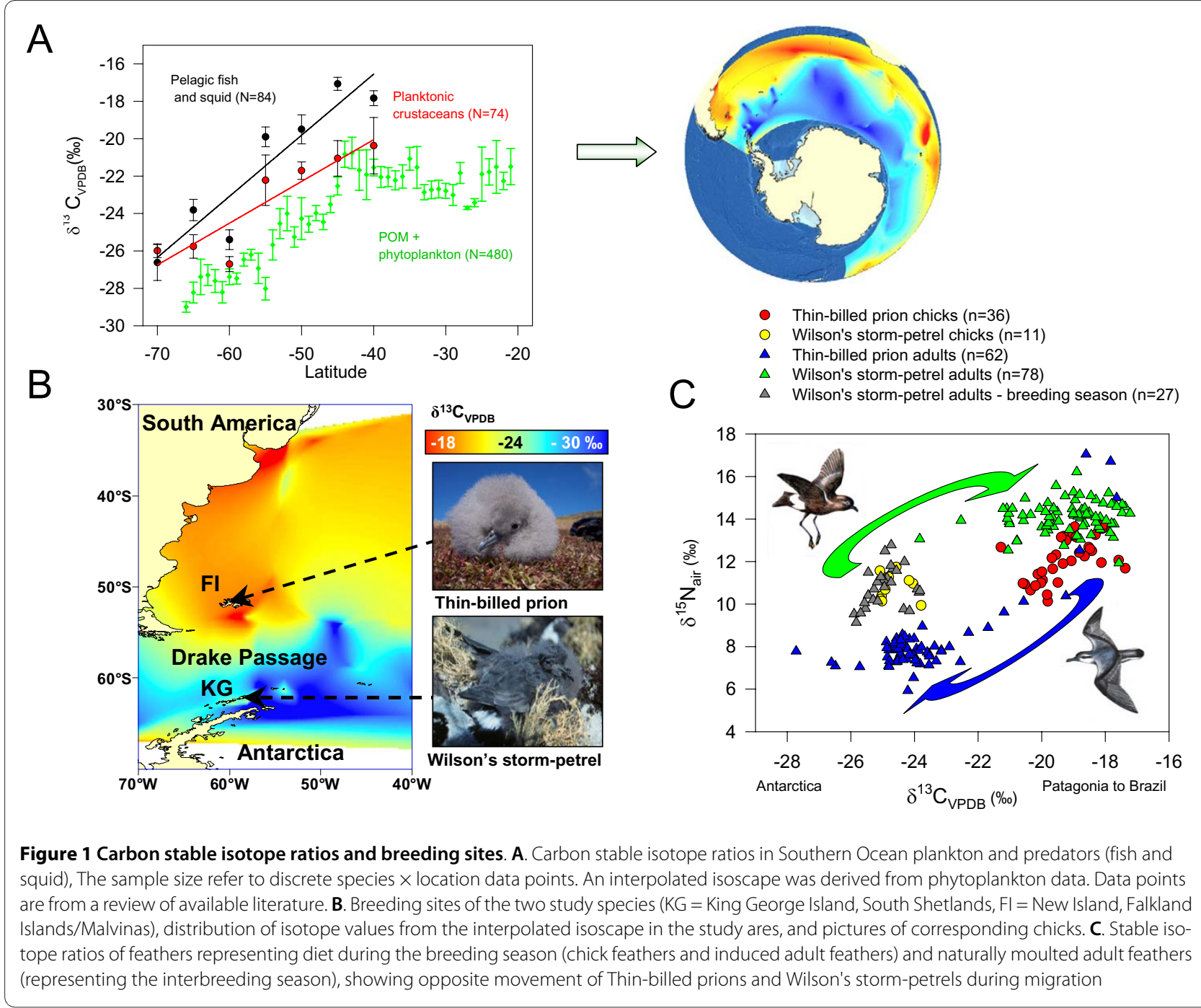


breeding season in the Falkland Islands or adjacent waters. The period 1913 - 1915, ninety years before the present study, was particularly well represented in museums. We compared the historical and recent samples after correcting for long-term-changes in $\delta^{13} \mathrm{C}$ due to the Suess effect (see methods below).

In summary, the aim of the present analysis was to model the $\delta^{13} \mathrm{C}$ distribution in the Southern Ocean as baseline for migration studies and to compare the migration pattern of Thin-billed prions in recent and historic times.

\section{Results}

\section{Southern ocean isoscape}

We compiled data from the literature to model the $\delta{ }^{13} \mathrm{C}$ distribution (Fig. 1A). Because ${ }^{13} \mathrm{C}$ was more enriched in higher trophic levels (Fig. 1A), we only used stable isotope ratios of pelagic primary producers to calculate a $\delta^{13} \mathrm{C}$ isoscape. The Southern Ocean in general, and the Southwest Atlantic in particular, exhibit a strong gradient in carbon stable isotope baseline values (Fig. 1A and 1B, see Fig. S1 in Supplementary material for additional details). This steep gradient ceases abruptly and completely at around $40-45^{\circ} \mathrm{S}$, the location (variable in latitudinal position around the globe) of the northern boundary of the Southern Ocean, defined through the Southern Subtropical Front.

\section{Recent feathers - comparison between two species}

Feathers grown during the breeding season reflected the more northerly breeding site of Thin-billed prions at the Falkland Islands, compared to Wilson's storm-petrels, breeding south of the Drake Passage (Fig. 1B,C). $\delta^{13} \mathrm{C}$ varied with species and time of the year, while the largest variation in the data was explained by the interaction between species and time (Table 1). The data thus confirm opposite migration movements: Most Thin-billed prions spent the summer north of the Polar Front, i.e. the northern limit of the Drake Passage, and the winter south, while Wilson's storm-petrels showed the opposite distribution (Fig. 1C). The $\delta^{13} \mathrm{C}$ values for Thin-billed prions in winter were very similar to those of Wilson's storm-petrels in summer $(-23.7 \pm 0.2 \%$ vs. $-24.9 \pm 0.1 \%$ o) and vice versa $(-19.2 \pm 0.1 \%$ for both Thin-billed prions in summer and Wilson's storm-petrels in winter). Some individuals of both species differed strikingly from the most common isotopic values, demonstrating some intra-specific flexibility in winter distribution.

The $\delta^{15} \mathrm{~N}$ signatures show that Wilson's storm-petrels maintained a relatively higher trophic level over the year (Fig. 1C). $\delta^{15} \mathrm{~N}$ was best explained by species differences $\left(\mathrm{P}<0.001, \eta^{2}=0.581\right)$, followed by location (represented by $\delta^{13} \mathrm{C}$ values: $\mathrm{P}<0.001, \eta^{2}=0.387$ ), while time and time"species interactions were of minor importance (Table 1).

\section{Comparison with historical feathers}

Historical and recent feathers of Thin-billed prions were isotopically distinct (Fig. 2A, Wilk's $\lambda=0.65, \mathrm{P}<0.001$ ). This was due to $3.3 \%$ lower carbon isotope ratios in recent compared with historical feathers $(-23.7 \pm 0.2 \%$ o vs. $-20.4 \pm 0.3 \%$ ). Thus, more Thin-billed prions $(92 \%)$ moult in Antarctic waters now than historically (45\%), using a cut-off point of $-21 \%$ (see Fig. $2 \mathrm{~A}$ ). This was based on a frequency distribution of observed $\delta^{13} \mathrm{C}$ values, which had a bimodal distribution, with a minimum at $-21 \%$ (Fig. 2A). The nitrogen stable isotope ratio remained constant over time (Table 2: $\mathrm{P}=0.51$, see also Fig. 2B for similar regression lines).

We analysed samples from eight Thin-billed prions collected at Rinconada beach in Chile in the summers 1968 and 1969, 21 birds from Argentinean beaches, collected between 1974 and 1984 and four birds collected at beaches in Brazil in 1997 and 2002 (Fig. 3). All except one bird had carbon isotope ratios indicating northern moulting areas.

In Wilson's storm-petrels, historical and recent feathers were also isotopically distinct (Fig. 2A, Wilk's $\lambda=0.93$, P $=0.043$ ), but the high Wilk's $\lambda$ (close to 1 ) and P-value (close to 0.05 ) indicated that the group means are by far less different than those observed in Thin-billed prions (Fig 2B). Comparatively small differences $(1.0 \%$ ) were observed in mean carbon isotope ratios in recent compared with historical feathers of Wilson's storm-petrels ($19.2 \pm 0.1 \%$ vs. $-18.2 \pm 0.2 \%$; $\mathrm{t}=2.5$, d.f. $85, \mathrm{P}=0.015)$, while nitrogen stable isotope ratios did not differ $(\mathrm{t}=0.9$, d.f. $85, \mathrm{P}=0.368$ ).

\section{Discussion}

In the present study, we found that two small pelagic seabirds had contrasting migratory patterns, and that the recent distribution of moulting Thin-billed prions with predominantly poleward winter migration differed from that observed historically. The trophic level of Thinbilled prions, in contrast, remained constant over time, suggesting that prions responded to changes in their environment by moving to a different location, while any possible changes in diet would be limited to dietary sources of similar trophic level. Wilson's storm-petrel feathers showed a much smaller change in carbon isotope ratios (Fig. 2B and 3B), indicating that baseline level changes alone would not explain the observed differences in Thin-billed prions. In addition, the shift in isotope ratio in Thin-billed prions is really large, almost certainly too large to be caused by changing primary productivity.

Consistency in trophic level is also seen in the comparison between the species, where Wilson's storm-petrels 
Table 1: Differences between species and times of the year in stable isotope ratios.

\begin{tabular}{|c|c|c|c|c|c|c|}
\hline Source & $\begin{array}{l}\text { Type III Sum } \\
\text { of Squares }\end{array}$ & $d f$ & Mean Square & $\boldsymbol{F}$ & $P$ & $\eta 2$ \\
\hline \multicolumn{7}{|c|}{ Dependent: $\delta^{13} \mathrm{C}$} \\
\hline species & 17.9 & 1 & 17.9 & 9.7 & 0.002 & 0.044 \\
\hline time & 16.6 & 1 & 16.6 & 9.0 & 0.003 & 0.041 \\
\hline species $\times$ time & 1226.7 & 1 & 1226.7 & 666.1 & $<0.001$ & 0.760 \\
\hline Error & 386.7 & 210 & 1.8 & & & \\
\hline Total & 1698.9 & 213 & & & & \\
\hline \multicolumn{7}{|c|}{ Dependent: $\delta^{15} \mathrm{~N}$} \\
\hline$\delta^{13} \mathrm{C}$ & 138.2 & 1 & 138.2 & 131.9 & $<0.001$ & 0.387 \\
\hline species & 303.1 & 1 & 303.1 & 289.4 & $<0.001$ & 0.581 \\
\hline time & 18.3 & 1 & 18.3 & 17.5 & $<0.001$ & 0.077 \\
\hline species $\times$ time & 3.5 & 1 & 3.5 & 3.3 & 0.070 & 0.016 \\
\hline Error & 218.9 & 209 & 1.0 & & & \\
\hline Total & 1540.3 & 213 & & & & \\
\hline
\end{tabular}

Carbon and nitrogen stable isotope ratios were measured in feathers of Thin-billed prions and Wilson's storm-petrels (winter vs. summer), tested using GLM. Location $\left(\delta^{13} \mathrm{C}\right)$ was included in the model for nitrogen to account for differences in baseline levels with latitude (e.g. see Fig. 2B).

maintained a relatively higher trophic level over the year (Table 1), and in historical feathers (Fig. 2B). This is consistent with observations from regurgitated food during the breeding season. Wilson's storm-petrels commonly took Antarctic krill Euphausia superba and lanternfish Electrona antarctica of 15-50 mm during summer [15], while Thin-billed prions fed predominantly on small crustaceans of 2-20 mm, mainly amphipods Themisto gaudichaudii, copepods Calanus spec., krill Euphausia lucens and lobster krill Munida gregaria [10,16]. Thus, Thin-billed prions, although nearly four times heavier than Wilson's storm-petrels, consistently took smaller prey and fed at a lower trophic level than the stormpetrels, as reflected in lower $\delta^{15} \mathrm{~N}$ signatures (Fig. 1C).

The observed differences in the migratory strategies between the species can most likely be explained by dif- ferences in the body size and in the abundance and distribution of their preferred prey. Wilson's storm-petrels are the smallest Antarctic endotherms at $38 \mathrm{~g}$, and low winter temperatures might constrain their distribution. In winter, they scatter widely but are often observed over the Patagonian Shelf. Lanternfish (myctophiids) are the most abundant small pelagic fish in the area, with larvae occurring throughout the year [17]. As lanternfish are one of the preferred prey of Wilson's storm-petrels [15], the shelf-break zone offers good feeding opportunities for them in winter. Additionally, Wilson's storm-petrels attend feeding flocks following fisheries vessels to pick up small pieces of discards and may benefit from increased human activity [18].

In contrast, Thin-billed prions do not attend vessels. They depend on lower trophic level prey, especially

Table 2: Comparison of nitrogen stable isotope ratios of Thin-billed prions breeding in the Falkland Islands.

\begin{tabular}{|c|c|c|c|c|c|c|}
\hline Source & $\begin{array}{l}\text { Type III Sum } \\
\text { of Squares }\end{array}$ & $d f$ & Mean Square & $\boldsymbol{F}$ & $P$ & $\eta 2$ \\
\hline \multicolumn{7}{|c|}{ Dependent: $\delta^{15} \mathrm{~N}$} \\
\hline$\delta^{13} \mathrm{C}$ & 577.4 & 1 & 577.4 & 300.7 & $<0.001$ & 0.713 \\
\hline time & 0.8 & 1 & 0.8 & 0.4 & 0.510 & 0.004 \\
\hline Error & 232.3 & 121 & 1.9 & & & \\
\hline Total & 1078.6 & 123 & & & & \\
\hline
\end{tabular}

Differences between historical and recent feathers were tested using GLM. Location $\left(\delta^{13} \mathrm{C}\right)$ was included in the model to account for differences in baseline levels with latitude (e.g. see Fig. 2B). 

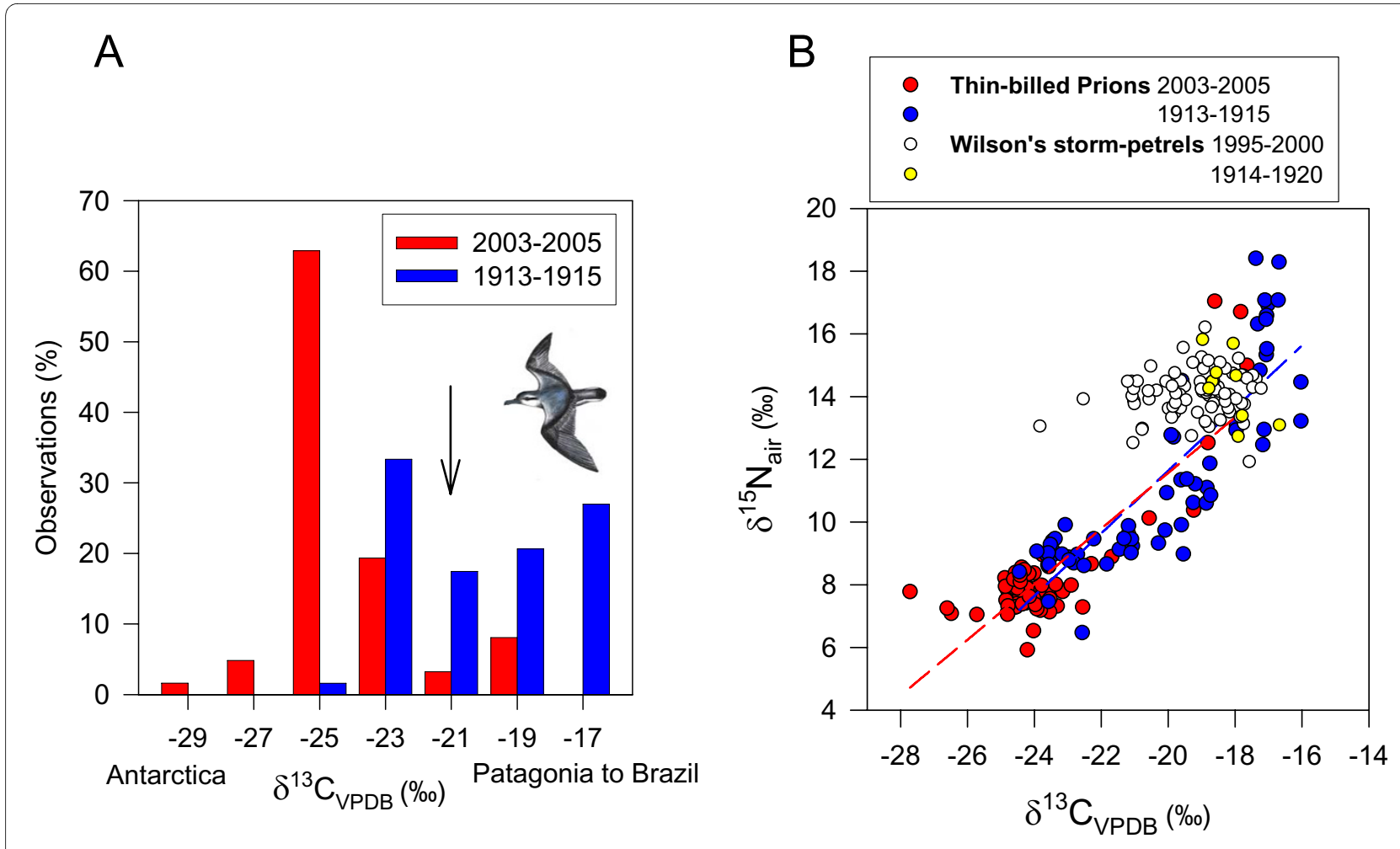

Figure 2 Differences in carbon stable isotope ratios of feathers of adult Thin-billed prions. Recent samples $(N=62)$ were collected at New Island, and historical samples $(\mathrm{N}=62)$ are from museum specimens. Histogram categories in $2 \mathrm{~A}$ had a width of $2 \%$, with labels showing the midpoint. In 2B, recent and historic samples of Wilson's storm-petrels were included for comparison.

amphipods Themisto gaudichaudii $[10,16]$, which occur throughout the Southern Ocean including the Patagonian shelf [19], mainly feeding on copepods. The ecosystem of the Patagonian shelf is strongly influenced by temperature. Massive blooms of gelatinous zooplankton occurred when the water temperature rose by $2^{\circ} \mathrm{C}$, rendering the tidal fronts off Patagonia less prominent and depressing copepod populations [20]. Rising sea temperatures might therefore cause significant bottom-up effects in the food chain.

Could such effects have caused the shift in the frequency of migration routes of Thin-billed prions? High rates of genetic change in preferred migratory direction have been observed in blackcaps Sylvia atricapilla as a consequence of assortative mating [21], indicating that the evolution of new migratory preferences can be remarkably rapid in birds. It is not known to which degree the direction of migration is genetically determined in seabirds. A recent study on the faithfulness of individual Thin-billed Prions to a moulting area within and among years suggested a flexible migratory strategy [22]. Feathers of marked Thin-billed Prions were sampled over several seasons. Although individuals moulting in an area in one year were more likely to do so again in the subsequent year, several birds changed between Antarctic and South American moulting areas or vice versa [22].

Hence, both genetic and phenotypic mechanisms could cause a change in migratory direction if birds that migrated (and moulted) north suffered a higher mortality than birds migrating to the Antarctic. There is, in fact, evidence that Thin-billed prions were affected by several large-scale mortality events, with major wrecks in New Zealand in 1974 and 1986 [23], in South Africa in 1984 [24] and in Brazil in 1954, 1982, 1984 and 1996 [25]. During the 1996 event in Brazil alone over 10,000 individuals were beached, and unknown numbers of birds died at sea. These major wrecks all occurred in the middle of winter (July-August), beached birds were underweight, without large fat deposits and with empty stomachs and many birds that were found dying soon recovered once receiving adequate food. These observations suggest that winter mortality can be high over the Patagonian Shelf and other northern moulting areas, and that the most likely cause of these events are food scarcities in mid winter. Abnormal weather conditions were not regularly observed during these events, and were interpreted as proximal cause of strandings of birds in already poor condition [25]. The present data suggest that winter mortal- 


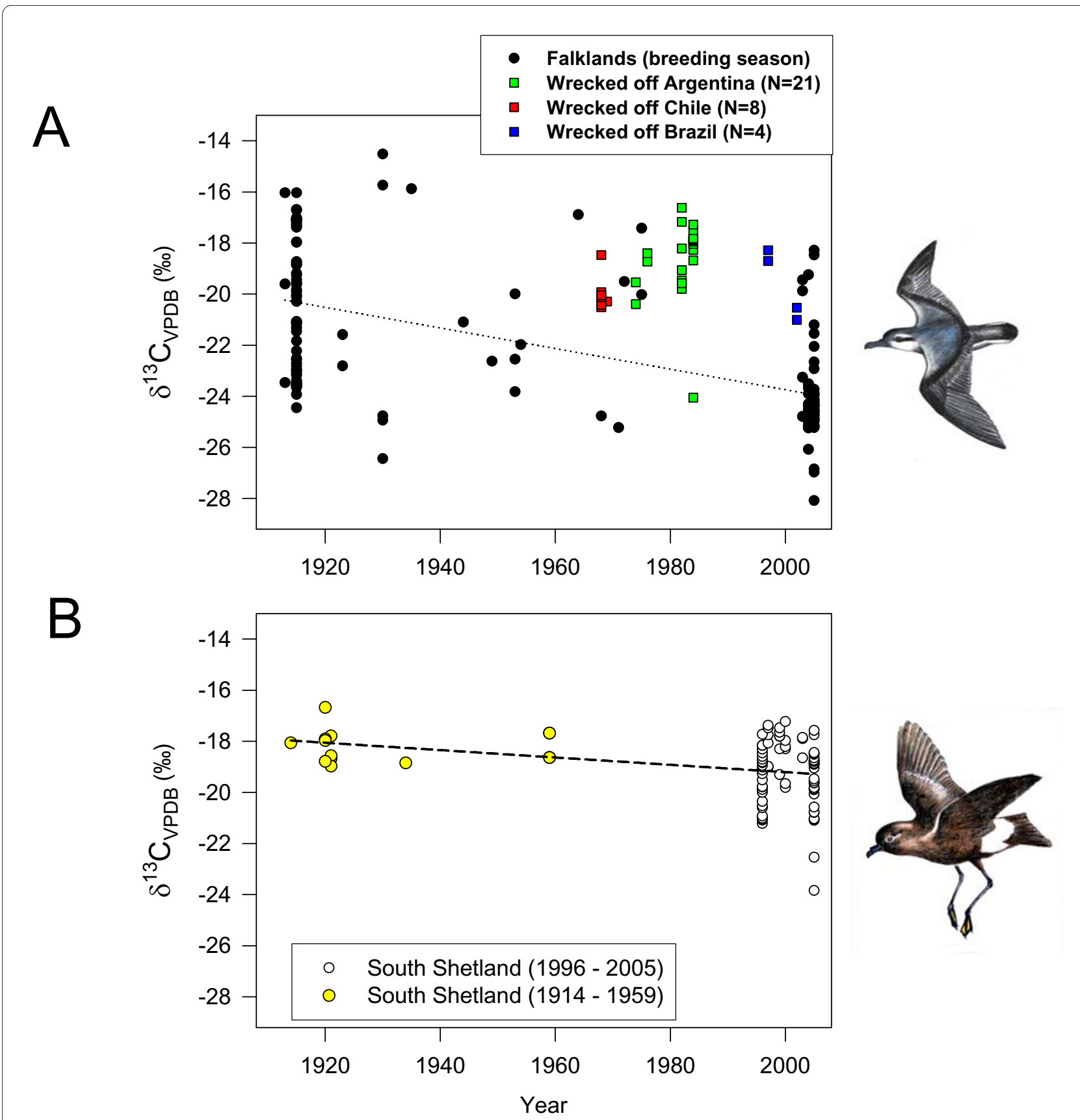

Figure 3 Stable isotope ratios of Thin-billed prions from wrecks. Carbon stable isotope ratios of birds found dead on beaches in winter, compared to birds sampled in the Falklands Islands in the breeding season. The dotted trendline was calculated from the breeding season birds only, but the clustered data distribution did not allow us a regression analysis. In 3B, recent and historic samples of Wilson's storm-petrels were included for comparison.

ity might have hit preferentially northern moulting birds (Fig. 3), although data on mortality in the south are lacking.

Given their large populations there are surprisingly few sightings of Thin-billed prions in the Antarctic, and their winter distribution has mainly been inferred from beached recoveries. This may be partly due to the absence of observers in the vast open ocean area, and due to the fact that Thin-billed prions are not concentrated at the ice edge as some other, more readily observed species [26].

Thin-billed prions are not the only seabird migrating polewards for the winter. Blue petrels Halobaena caerulea are a closely related species, which replace Thin-billed 
prions in some parts of their circumpolar range, such as South Georgia. They have very similar stable isotope signatures [[27], adult Blue petrel feathers from South Georgia: $\delta^{13} \mathrm{C}=-24.1 \pm 0.9$ and $\delta^{15} \mathrm{~N}=7.9 \pm 0.5$ ], indicating similar latitude and trophic level during moult. In fact, they are often observed in feeding flocks together with prions [28].

\section{Conclusions}

In conclusion, the present data strongly suggest a change of migration patterns in a small pelagic seabird. There are fundamental differences from the migration of land birds with their major flyways and overwhelmingly equator ward direction. In the polar oceans, the primary productivity is restructured in winter, and can be very high in near-surface waters, thus generating migration towards the polar areas. Our data from Thin-billed prions further support this view, and indicate that seabird migration patterns may quickly respond to changes such as those caused by global warming.

\section{Methods}

The fieldwork was carried out in the framework of longterm studies and under licence (Falkland Islands Government Environmental Planning Department, Umweltbundesamt Germany).

\section{The Southern Ocean carbon isoscape}

Authors sampling in different areas of the Southern Ocean noted a southward decline in $\delta^{13} \mathrm{C}$ of phytoplankton and subsequently, higher, trophic level organisms $[9,10]$. Across the Drake Passage, the area relevant to the present study, a $7 \%$ gradient in the $\delta^{13} \mathrm{C}$ of suspended particulate organic matter (POM) has been observed, from $-23.2 \%$ at $53^{\circ} \mathrm{S}$ to values as low as $-30.3 \%$ at $62^{\circ} \mathrm{S}$ [11].
The southward decline in $\delta^{13} \mathrm{C}$ does not track the abrupt changes in water chemistry and plankton species composition associated with the Polar Front Zone, but show a rather gradual change with latitude $[11,29]$. Studies did not report any significant changes in phytoplankton carbon or nitrogen concentrations or $\mathrm{C} / \mathrm{N}$ ratios with latitude (e.g. Drake Passage: [11]], which would be indicative of differences in plankton standing crop or biochemistry (e.g., lipid content). The latitudinal change in $\delta^{13} \mathrm{C}$ was, however, highly correlated with sea surface temperatures and with the calculated concentration of $\mathrm{CO}_{2}(\mathrm{aq})$ at equilibrium with atmospheric $\mathrm{CO}_{2}[11,29]$, suggesting that $\mathrm{CO}_{2}(\mathrm{aq})$ significantly influences $\delta^{13} \mathrm{C}$ in ocean surface waters, and throughout the food chain.

For latitudinal trends and comparison of trophic levels (Fig. 1A), we compiled data published in the Southern Ocean for $\delta^{13} \mathrm{C}$ of phytoplankton and POM [29-41], planktonic crustaceans $[10,12,33,36-40,42-48]$ and pelagic fish and squid [10,12,32,37,38,40,42,44,48-52]. Gerhard Fischer, University of Bremen, kindly provided an unpublished dataset from Fig. 1 of [34]. We used ArcView 9.3 (ESRI), to plot the distribution of 326 sampling locations for phytoplankton and POM from $30^{\circ} \mathrm{S}$ southwards (Fig. 4), and we used a nearest-neighbor interpolation in the Spatial Analyst tool to model and visualize the latitudinal trend in $\delta^{13} \mathrm{C}$ (Fig. S1, see also Fig. $1 \mathrm{~A}, \mathrm{~B})$.

\section{Study site, study species and feather samples}

Samples of Thin-billed prions were collected as part of an ongoing study at New Island Nature Reserve, Falkland Islands $\left(51^{\circ} 43^{\prime} \mathrm{S}, 61^{\circ} 17^{\prime} \mathrm{W}\right)$ during three consecutive breeding seasons $(2003 / 04,2004 / 05,2005 / 06)$. We collected samples representing birds outside the breeding season (adult rectrices and undertail coverts), as well as the breeding season (chick undertail coverts), by gentle pulling and placed them in individual plastic bags. The

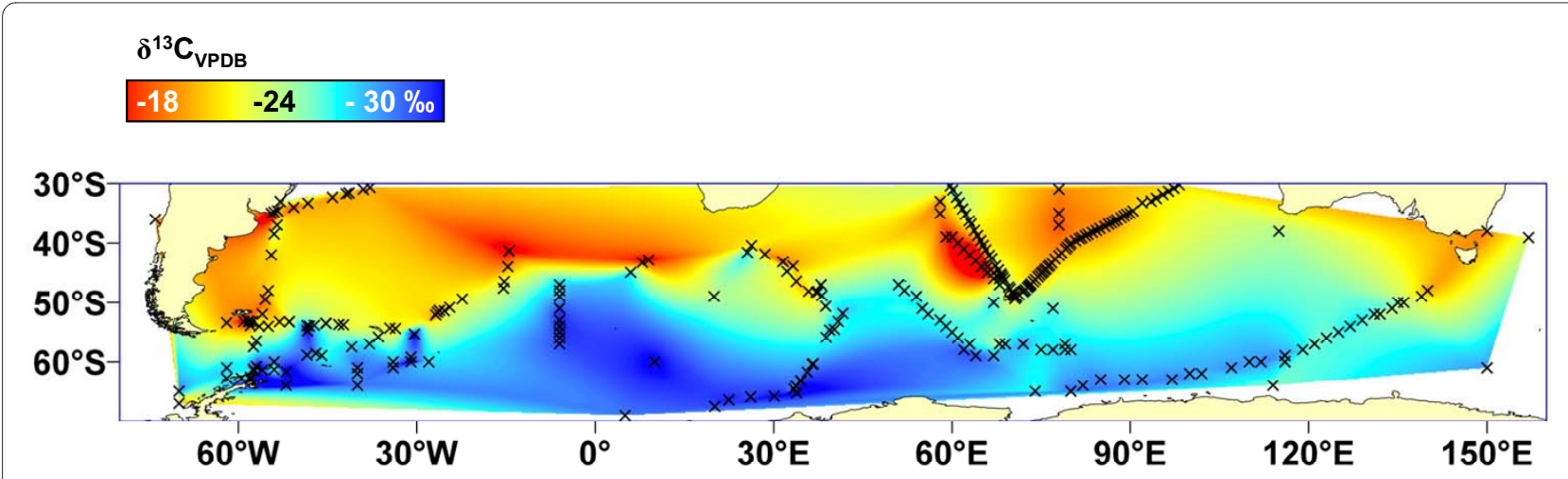

Figure 4 The calculated isoscape after interpolation. Sample locations are marked with crosses. All data were included as given in the original papers, for further details, please see the methods section. 
first tail feathers of chicks including the tail coverts start to emerge after 3 weeks of age [[16], p. 427: 'at $22 \mathrm{~d}$ the sheaths of the rectrices can be felt protruding']; therefore, the distal parts of these feathers represent the middle of the nestling growth period of $50 \mathrm{~d}$ (i.e. about $25 \mathrm{~d}$ ).

Wilson's storm-petrels have a circumpolar breeding distribution in the Antarctic. This species is described as a transequatorial migrant [28], although winter records in the southern hemisphere are also common, for example off Brazil in the Atlantic [18] or off Peru in the Pacific [28]. This northerly migration movement of Wilson's storm-petrels was well reflected by the stable isotope signatures of adult and chick feathers sampled at King George Island, South Shetlands [9,14], and stable isotopes helped to establish that these birds move further south, towards the sea ice edge, to feed up for egg production [9] and that their wintering areas differ between years, depending on the location of rich frontal systems [14]. Wilson's storm-petrels moult their feathers in the winter quarters, and thus, at a similar time to Thin-billed prions (see below).

Sample collection took place in the Tres Hermanos (Three Brothers Hill) colony on King George Island $\left(62^{\circ} 14^{\prime} \mathrm{S}, 58^{\circ} 40^{\prime} \mathrm{W}\right)$, South Shetland Islands in the maritime Antarctic from December 1995 to April 2000. About 2000 pairs breed in this colony [53], and we have previously described their general breeding biology [summarized in [54]], diet [15] and provisioning patterns [[55] and references therein]. In 1995-1996, we collected 27 induced feathers of adult Wilson's storm-petrels as part of a ptilochronology study. The outermost right rectrix was pulled during a first control in February 1996 and induced feathers were collected at the time of recapture, in late March 1996. The time of feather growth was thus in the chick-rearing period, simultaneously with growing chick feathers.

\section{Comparison of stable isotope ratios in chick feathers and simultaneously grown induced adult feathers}

The findings of a previous analysis indicated that adult and chick feathers undergo a similar isotopic enrichment compared to blood within and between species of Procellariiformes [56]. We compared 27 adult and 11 chick feathers of Wilson's storm-petrels grown simultaneously during the breeding season (Fig. 1C). They were not isotopically distinct (Wilk's $\lambda=0.96, \mathrm{P}=0.493$ ). As wing, tail and body feathers are grown in the second part of the long nestling periods of petrel chicks, the tissue has already undergone a nearly complete tissue turnover since hatching. Although isotopic enrichment compared to diet was not determined specifically, similar isotope values in chicks and adults suggest that in these species, chick feathers reliably reflect the diet during the breeding season.

\section{Historical feathers}

We included 115 feather samples from museum specimens of Thin-billed prions as listed below, including 82 samples from birds collected in the Falkland Islands and adjacent waters in the breeding season, and 33 samples of birds collected dead on beaches in Chile, Argentina and Brazil. We further included 14 historical feathers from Wilson's storm-petrels collected in the South Shetland Islands. Preferably, undertail feathers were taken, or flank feathers if sampling undertail feathers was not permitted. Sequentially moulted primaries indicated that most adults maintained highly conserved isotope values over the entire wing moulting period [22], and previous analyses had shown that undertail feathers, rectrices and flank feathers did not show significantly different stable isotope values. Because in Thin-billed prions, all moult occurs outside of the breeding season [16], and chicks of Thinbilled prions do not fledge until March, we are confident that flank feathers, rectrices and undertail feathers all represent the late autumn and early winter period (AprilJuly). Tail feathers are moulted towards the end of the wing moulting period, which takes 2-4 months in prion species [57], and thus, tail feathers are moulted in early winter in Thin-billed prions.

We obtained samples of Thin-billed prions of the following museums specimens: American Museum of Natural History New York, USA: \#445528-445541, 445544445549, 445552-445564, 445566-445577, 445579-445594, 792675, 792883-792887, Natural History Museum, Tring, UK: \# 1925.9.14.1, 1925.9.14.2, 1940.12.6.76, 1932.7.2.16, 1932.7.2.17, 1932.7.2.19-1932.7.2.23, 1949.52.10, 1951.51.2, 1969.2.2, 1969.2.2, 1972.14.1, Museo Argentino de Ciencias Naturales Bernardino Rivadavia, Buenos Aires, Argentina: \#42973, 42974, 52110, 52111, 52331, 52372, 52406, 52414, 52770-52774, Naturhistorisches Museum Wien, Austria: NMW 80.541 - 80.550, NMW 87.177, Biozentrum Grindel und Zool. Museum Hamburg, Germany: \# 75.106, 75.107, 75.133, Cornell University Museum of Vertebrates, USA: \# 25006, 25007, National Museum of Natural History Leiden, Netherlands: \# 3269, Museo de La Plata, Argentina: \#13326, Museu de Ciências e Tecnologia - PUCRS, Porto Alegre, Brazil: \# MCP0705, MCP1116, MCP1120, MCP1395.

We obtained samples of Wilson's storm-petrels of the following museums specimens: American Museum of Natural History New York, USA: \# 196198, 196199, 196202, 349447, Natural History Museum, Tring, UK: \# 1924.5.8.28, 1924.5.8.29, 1925.10.4.26, 1933.10.16.1, $1933.10 .16 .2,1940.12 .7 .48,1963.41 .2-5$.

\section{Sample preparation and stable isotope analysis}

Carbon and nitrogen isotope analyses were carried out on $0.65-0.7 \mathrm{mg}$ aliquots, weighed into tin cups. A single feather per sample was cut into small fragments using 
stainless steel scissors. Studies have shown that mean $\delta^{13} \mathrm{C}$ values did not shift when feathers were cleaned, supporting the notion that carbon stable isotope ratios are quite robust to minor contamination [58,59], and this is unlikely to be of any relevance given that differences observed in the present study between birds moulting in Antarctic and more northern areas were very large (-19 vs. $-25 \%$ ). As cleaning agents may remove contaminants but may also change feather isotope values, either by leaving a residue with a different enough stable isotope ratio to change the measured value or by causing atom exchange [e.g. [59]], we decided not to apply a cleaning protocol. We thus selected feathers free from any obvious contamination, both in recent and historical feathers.

Carbon and nitrogen isotope ratios were measured simultaneously by continuous-flow isotope ratio mass spectrometry (CF-IRMS) using a Costech Elemental Analyser (EA) linked to a Thermo Finnigan Delta Plus XP Mass Spectrometer. Two laboratory standards were analysed for every 10 unknown samples, allowing any instrument drift over a typical 14 hour run to be corrected. Stable isotope ratios were expressed in $\delta$ notation as parts per thousand $(\%)$ deviation from the international standards V-Pee dee belemnite (carbon) and AIR (nitrogen), according to the following equation $\delta \mathrm{X}=\left[\left(\mathrm{R}_{\text {sample }} / \mathrm{R}_{\text {stan- }}\right.\right.$ dard $)-1] \times 1000$ where $\mathrm{X}$ is ${ }^{15} \mathrm{~N}$ or ${ }^{13} \mathrm{C}$ and $\mathrm{R}$ is the corresponding ratio ${ }^{15} \mathrm{~N} /{ }^{14} \mathrm{~N}$ or ${ }^{13} \mathrm{C} /{ }^{12} \mathrm{C}$. Based on internal standards (tryptophan), the analytical precision ( $\pm 1 \mathrm{SD}$ ) was estimated as $\pm 0.18 \%$ and $\pm 0.17 \%$ or $\delta^{15} \mathrm{~N}$ and $\delta^{13} \mathrm{C}$, respectively.

\section{Data analysis}

Data analysis was carried out using SPSS 11.0. The isotopic ratios of storm-petrel feathers grown simultaneously were compared between groups using discriminant analysis (Wilk's $\lambda$ ). We ran general linear models GLM with time and species as categorical independent variables ('factor'). As a measure of effect sizes we included partial eta-squared values $\left(\eta^{2}\right)$ i.e. the proportion of the effect+error variance that is attributable to the effect. The sums of the $\eta^{2}$ values are not additive [e.g. [60]]. Normality was tested by Kolmogorov-Smirnov-tests and visual inspection. Only prion winter data (adult feathers) were not normally distributed. This was due to outliers ( 5 of 62 data points), and we therefore followed the suggestion of [61] and considered the test results only significant when $\mathrm{P}<0.01$. Otherwise, significance was assumed at $\mathrm{P}<0.05$, and means are given with standard errors.

\section{Historical samples}

Pools of fossil $\mathrm{CO}_{2}$ are depleted in ${ }^{13} \mathrm{C}$ compared to $\mathrm{CO}_{2}$ in the atmosphere. The burning of large amounts of fossil $\mathrm{CO}_{2}$ has diluted the atmospheric $\mathrm{CO}_{2}$ pool resulting in a more negative $\delta^{13} \mathrm{C}$ value. This has been termed the Suess effect [7]. The increasing concentration of $\mathrm{CO}_{2}$ in the atmosphere has also resulted in an increasing concentration of dissolved $\mathrm{CO}_{2}$ in the ocean, resulting in increasing $\delta^{13} \mathrm{C}$ values in phytoplankton during the last 150 years. When long time series of $\delta^{13} \mathrm{C}$ are analysed, the data have to be corrected for the Suess effect [7]. We normalized all data to the current end of our database, the year 2008, by subtracting a year-specific factor $\delta^{13} \mathrm{C}=-1+1.1^{(2008-}$ year) ${ }^{*} 0.027$ [7]. It should be noted that the effect is small compared to the large range of $\delta^{13} \mathrm{C}$ values observed here. For example, the estimated overall Suess effect from 1850 to 2002 is $0.62 \%$ for Falkland Island waters.

Rising sea surface temperatures reduce the amount of dissolved $\mathrm{CO}_{2}$ in the ocean, termed $\mathrm{CO}_{2}(\mathrm{aq})$. Because $\delta^{13} \mathrm{C}$ in phytoplankton is negatively correlated with $\mathrm{CO}_{2}$ (aq) [30], this leads to a minor enrichment of ${ }^{13} \mathrm{C}$, e.g. for the period 1850-2002 a maximum correction factor of $0.16 \%$ was modelled [7]. Because of this small influence, we did not correct for sea surface temperature variation.

\section{Competing interests}

The authors declare that they have no competing interests.

\section{Authors' contributions}

$P Q$, JFM, and RWF planned and carried out the study. RARMcG conducted the stable isotope analyses at the NERC Life Sciences Mass Spectrometry Facility, MA facilitated access to museums and hosted a Synthesys-funded museum study. PQ drafted the manuscript. All authors read and approved the final manuscript.

\section{Acknowledgements}

We gratefully acknowledge logistic support from New Island Conservation Trust (lan Strange), Falkland Islands Government, Alfred-Wegner-Institut Bremerhaven, Instituto Antártico Argentino, Friedrich-Schiller-Universität Jena (Hans-Ulrich Peter) and Nancy Clum (WCS). Anja Gladbach, Felix Weiss and Amanda Duckworth helped preparing samples, and museum curators kindly provided samples (Buenos Aires: Pablo Tubaro, Wien: Ernst Bauernfeind, Anita Gamauf, Hamburg: Cordula Bracker, Cornell: Kimberly Bostwick, Leiden: Hein van Grouw, Porto Alegre: Emilio Antônio Jeckel Neto, Carla Suertegaray Fontana) or access to the collections (New York: Paul Sweet, Margaret Hart, La Plata: Carlos Darrieu). Gerhard Fischer provided a dataset used in the isoscape. Stable isotope analyses were funded by NERC (UK). PQ received funding for the fieldwork from Deutsche Forschungsgemeinschaft, Germany (Qu 148). The visit to the Tring collections was fundend by the European Union (SYNTHESYS GB-TAF-4731). We are grateful to three anonymous referees who provided helpful comments.

\section{Author Details}

1 Max-Planck-Institut für Ornithologie, Vogelwarte Radolfzell, Schlossallee 2, 78315 Radolfzell, Germany, 2NERC Life Sciences Mass Spectrometry Facility, Scottish Universities Environmental Research Centre, East Kilbride, Glasgow G75 OQF, UK, ${ }^{3}$ Dept. of Zoology, The Natural History Museum, Akeman Street, Tring, Herts, HP23 6AP, UK and 4Faculty of Biomedical and Life Sciences, University of Glasgow, Glasgow G12 8QQ UK

Received: 4 March 2010 Accepted: 19 May 2010 Published: 19 May 2010

\footnotetext{
References

1. Newton I: The migration ecology of birds Oxford, UK, Elsevier; 2007.

2. Hobson KA, Wassernaar LI: Tracking animal migration with stable isotopes Amsterdam, Academic Press; 2008
} 
3. Thompson DR, Furness RW, Lewis SA: Diets and long-term changes in $\delta^{15} \mathrm{~N}$ and $\delta^{13} \mathrm{C}$ values in northern fulmars Fulmarus glacialis from two northeast Atlantic colonies. Mar Ecol Prog Ser 1995, 125:3-11.

4. Becker BH, Beissinger SR: Centennial decline in the trophic level of an endangered seabird after fisheries decline. Cons Biol 2006, 20:470-479,

5. Norris DR, Arcese P, Preikshot D, Bertram DF, Kyser TK: Diet reconstruction and historic population dynamics in a threatened seabird. J Appl Ecol 2007, 44:875-884

6. Thompson DR, Sagar P: Declining rockhopper penguin populations in New Zealand. Water Atmosph 2002, 10:10-12.

7. Hilton GM, Thompson DR, Sagar PM, Cuthbert RJ, Cherel Y, Bury SJ: A stable isotopic investigation into the causes of decline in a subAntarctic predator, the rockhopper penguin Eudyptes chrysocome. Global Change Biol 2006, 12:611-625.

8. Rau GH, Takahashi T, Des Marais DJ, Sullivan CW: Particulate organic matter $\delta 13 C$ variations across the Drake Passage. J Geophys Res 1991, 96:15131-15135.

9. Quillfeldt P, McGill RAR, Furness RW: Diet and foraging areas of Southern Ocean seabirds and their prey inferred from stable isotopes: review and case study of Wilson's storm-petrel. Mar Ecol Prog Ser 2005, 295:295-304.

10. Quillfeldt P, McGill RAR, Strange IJ, Masello JF, Weiss F, Brickle P, Furness RW: Stable isotope analysis reveals sexual and environmental variability and individual consistency in foraging of Thin-billed Prions. Mar Ecol Prog Ser 2008, 373:137-148.

11. Cherel Y, Hobson KA: Geographical variation in carbon stable isotope signatures of marine predators: a tool to investigate their foraging areas in the Southern Ocean. Mar Ecol Prog Ser 2007, 329:281-287.

12. Cherel Y, Bocher P, De Broyer C, Hobson KA: Food and feeding ecology of the sympatric thin-billed Pachyptila belcheri and Antarctic P. desolata prions at lles Kerguelen, Southern Indian Ocean. Mar Ecol Prog Ser 2002, 228:263-281

13. Cherel Y, Phillips RA, Hobson KA, McGill R: Stable isotope evidence of diverse species-specific and individual wintering strategies in seabirds. Biol Letters 2006, 2:301-303.

14. Gladbach A, McGill RAR, Quillfeldt P: Foraging areas of Wilson's stormpetrel Oceanites oceanicus in the breeding and inter-breeding period determined by stable isotope analysis. Polar Biol 2007, 30:1005-1012.

15. Quillfeldt $P$ : Seasonal and annual variation in the diet of breeding and non-breeding Wilson's storm-petrels on King George Island, South Shetland Islands. Polar Biol 2002, 25:216-221.

16. Strange IJ: The thin-billed prion, Pachyptila belcheri, at New Island, Falkland Islands. Gerfaut 1980, 70:411-445.

17. Sánchez RP, de Ciechomski JD: Spawning and nursery grounds of pelagic fish species in the sea-shelf off Argentina and adjacent areas. Scientia Marina 1995, 59:455-478.

18. Bugoni L, Mancini PL, Monteiro DS, Nascimento L, Neves TS: Seabird bycatch in the Brazilian pelagic longline fishery and a review of capture rates in the southwestern Atlantic Ocean. Endang Species Res 2008, 5:137-147.

19. Ramírez FC, Viñas MD: Hyperiid amphipods found in Argentine shelf waters. Physis (Buenos Aires) Secc A 1985, 43:25-37.

20. Sabatini M, Martos P: Mesozooplankton features in a frontal area off northern Patagonia (Argentina) during spring 1995 and 1998. Scientia Marina 2002, 66:215-232.

21. Bearhop S, Fielder W, Furness RW, Votier SC, Waldron S, Newton J, Bowen GJ, Berthold P, Farnsworth K: Assortative mating as a mechanism for rapid evolution of a migratory divide. Science 2005, 310:502-504.

22. Quillfeldt P, Voigt CC, Masello JF: Plasticity versus repeatability in seabird migratory behaviour. Behav Ecol Sociobio/ 2010 in press.

23. Powlesland RG: Seabirds found dead on New Zealand beaches in 1986 and a review of Pachyptila species recoveries since 1960. Notornis 1989, 36:125-140

24. Ryan PG, Avery G, Rose B, Ross GJB, Sinclair JC, Vernon CJ: The Southern Ocean seabird irruption to South African waters during winter 1984. Cormorant 1989, 17:41-55.

25. Martuscelli P, Silva e Silva R, Olmos F: A large Prion Pachyptila wreck in south-east Brazil. Cotinga 1997, 8:55-57.

26. Ainley DG, Jacobs SS, Ribic CA, Gaffney I: Seabird distribution and oceanic features of the Amundsen and southern Bellingshausen seas. Antarct Sci 1998, 10:111-123.
27. Cherel $Y$, Bocher $P$, Trouvé $C$, Weimerskirch H: Diet and feeding ecology of blue petrels Halobaena caerulea at Iles Kerguelen, Southern Indian Ocean. Mar Ecol Prog Ser 2002, 228:283-299.

28. Harrison P: Seabirds - an identification guide London: Christopher Helm; 1985.

29. Dehairs F, Kopczynska E, Nielsen P, Lancelot C, Bakker DCE, Koeve W, Goeyens $L: \delta^{13} C$ of Southern Ocean suspended organic matter during spring and early summer: regional and temporal variability. Deep Sea Res II 1997, 4:129-142.

30. Francois R, Altabet MA, Goericke R, McCorkle DC, Brunet C, Poisson A: Changes in the $\delta^{13} \mathrm{C}$ of surface water particulate organic matter across the subtropical convergence in the SW Indian Ocean. Global Biogeochem Cycles 1993, 7:627-644.

31. Bentaleb I, Fontugne M, Descolas-Gros C, Girardin C, Mariotti A, Pierre C, Brunet C, Poisson A: Carbon isotopic fractionation by plankton in the Southern Indian Ocean: relationship between delta C-13 of particulate organic carbon and dissolved carbon dioxide. J Mar Syst 1998, 17:39-58.

32. Davenport SR, Bax NJ: A trophic study of a marine ecosystem off southeastern Australia using stable isotopes of carbon and nitrogen. Can J Fish Aquat Sci 2002, 59:514-530.

33. Eadie $B J$, Jeffrey $L M: \delta^{13} C$ analyses of oceanic particulate organic matter. MarChem 1973, 1:199-209.

34. Fischer $G$, Müller $P$, Wefer $G$ : Latitudinal $\delta^{13} \mathrm{C}$ (org) variations in sinking matter and sediments from the South Atlantic: effects of anthropogenic $\mathrm{CO}_{2}$ and implications for paleo- $\mathrm{PCO}_{2}$ reconstructions. J Mar Syst 1998, 17:471-495.

35. Fontugne M, Duplessy JC: Carbon isotope ratio of marine plankton related to surface water masses. Earth Planetary Sci Letters 1978, 41:365-371

36. Frazer TK: Stable isotope composition $\left(\delta^{13} \mathrm{C}\right.$ and $\left.\delta^{15} \mathrm{~N}\right)$ of larval krill, Euphausia superba, and two of its potential food sources in winter. $J$ Plankton Res 1996, 18:1413-1426.

37. Hückstädt LA, Rojas CP, Antezana T: Stable isotope analysis reveals pelagic foraging by the Southern sea lion in central Chile. J Exp Mar Biol Ecol 2007, 347:123-133.

38. Kaehler S, Pakhomov EA, McQuaid CD: Trophic structure of the marine food web at the Prince Edward Islands (Southern Ocean) determined by $\delta^{13} \mathrm{C}$ and $\delta^{15} \mathrm{~N}$ analysis. Mar Ecol Prog Ser 2000, 208:13-20.

39. Schmidt K, Atkinson A, Stubing D, McClelland JW, Montoya JP, Voss M: Trophic relationships among Southern Ocean copepods and krill: Some uses and limitations of a stable isotope approach. Limnol Oceanogr 2003, 48:277-289.

40. Wada E, Terazaki M, Kabaya Y, Nemoto T: ${ }^{15} \mathrm{~N}$ and ${ }^{13} \mathrm{C}$ abundances in the Antarctic Ocean with emphasis on the biogeochemical structure of the food web. Deep Sea Res 1987, 34:829-841.

41. Sackett WM, Eckelmann WR, Bender ML, Be AWH: Temperature dependence of carbon isotope composition in marine plankton and sediments. Science 1965, 148:235.

42. Cherel Y: Isotopic niches of emperor and Adelie penguins in Adelie Land, Antarctica. Mar Biol 2008, 154:813-821.

43. Corbisier TN, Petti MAV, Skowronski RSP, Brito TAS: Trophic relationships in the nearshore zone of Martel Inlet (King George Island, Antarctica): $\delta^{13} \mathrm{C}$ stable-isotope analysis. Polar Biol 2004, 27:75-82.

44. Dunton $\mathrm{KH}: \delta^{15} \mathrm{~N}$ and $\delta^{13} \mathrm{C}$ measurements of Antarctic peninsula fauna: Trophic relationships and assimilation of benthic seaweeds. Am Zool 2001, 41:99-112.

45. Hall-Aspland SA, Rogers TL, Canfield RB: Stable carbon and nitrogen isotope analysis reveals seasonal variation in the diet of leopard seals. Mar Ecol Prog Ser 2005, 305:249-259.

46. Mizutani H, Wada E: Nitrogen and carbon isotope ratios in seabird rookeries and their ecological implications. Ecology 1988, 69:340-349.

47. Thompson DR, Furness RW: Stable-isotope ratios of carbon and nitrogen in feathers indicate seasonal dietary shifts in northern Fulmars. Auk 1995, 112:493-498.

48. Tierney M, Southwell C, Emmerson LM, Hindell MA: Evaluating and using stable-isotope analysis to infer diet composition and foraging ecology of Adélie penguins Pygoscelis adeliae. Mar Ecol Prog Ser 2008 355:297-307.

49. Burns JM, Trumble SJ, Castellini MA, Testa JW: The diet of Weddell seals in McMurdo Sound, Antarctica as determined from scat collections and stable isotope analysis. Polar Biol 1998, 19:272-282. 
50. Cherel Y, Hobson KA, Weimerskirch H: Using stable-isotope analysis of feathers to distinguish moulting and breeding origins of seabirds. Oecologia 2000, 122:155-162.

51. Forero MG, Bortolotti GR, Hobson KA, Donazar JA, Bertelloti M, Blanco G: High trophic overlap within the seabird community of Argentinean Patagonia: a multiscale approach. J Anim Ecol 2004, 73:789-801.

52. Zimmer I, Piatkowski U, Brey T: The trophic link between squid and the emperor penguin Aptenodytes forsteri at Pointe Geologie, Antarctica. Mar Biol 2007, 152:1187-1195.

53. Hahn S, Peter H-U, Quillfeldt P, Reinhardt K: The birds of the Potter Peninsula, King George Island, South Shetland Islands, 1965-1998. Mar Orn 1998, 26:1-6.

54. Quillfeldt P: Wilson's storm-petrel. In Encyclopedia of the Antarctic Edited by: Riffenburgh B. New York: Routledge; 2007:1081-1084.

55. Gladbach A, Büßer C, Mundry R, Quillfeldt P: Acoustic parameters of begging calls indicate chick body condition and influence parental feeding decisions in Wilson's storm-petrels Oceanites oceanicus. J Ethol 2009, 27:267-274.

56. Quillfeldt P, Bugoni L, McGill RAR, Masello JF, Furness RW: Differences in stable isotopes in blood and feathers of seabirds are consistent across species, age and latitude - implications for food web studies. Mar Biol 2008, 155:593-598.

57. Bridge ES: Influences of morphology and behavior on wing-molt strategies in seabirds. Mar Orn 2006, 34:7-19.

58. Mizutani $\mathrm{H}$, Fukuda M, Kabaya Y: C-13 enrichment and N-15 enrichment factors of feathers of 11 species of adult birds. Ecology 1992, 73:1391-1395

59. Paritte JM, Kelly JF: Effect of cleaning regime on stable-isotope ratios of feathers in Japanese quail (Coturnix japonica). Auk 2009, 126:165-174

60. Effect size (ES) [http://web.uccs.edu/lbecker/SPSS/glm effectsize.htm]

61. Zöfel P: Statistik verstehen. Ein Begleitbuch zur computergestützten Anwendung München: Addison-Wesley; 2002.

doi: $10.1186 / 1742-9994-7-15$

Cite this article as: Quilffeldt et al., Moving polewards in winter: a recent change in the migratory strategy of a pelagic seabird? Frontiers in Zoology 2010, 7:15

Submit your next manuscript to BioMed Central and take full advantage of:

- Convenient online submission

- Thorough peer review

- No space constraints or color figure charges

- Immediate publication on acceptance

- Inclusion in PubMed, CAS, Scopus and Google Scholar

- Research which is freely available for redistribution

Submit your manuscript at www.biomedcentral.com/submit
C) Biomed Central 